Niniejsza publikacja jest dostepna na licecji Creative Commons. Uznanie autorstwa-Użycie niekomercyjne-Bez utworów zależnych 3.0 Polska. Pewne prawa zastrzeżone na rzecz autora. Zezwala się na wykorzystanie publikacji zgodnie z licencja - pod warunkiem zachowania niniejszej informacji licencyjnej oraz wskazania autora jako właściciela praw do tekstu. Treść licencji jest dostępna na stronie: http://creativecommons.org/licenses/by-nc-nd/3.0/pl/

Lingwistyka Stosowana 24: 4/ 2017, 23-35

\author{
Anna BONEK \\ Uniwersytet Warszawski
}

\title{
Rozszerzenie podstaw rekonstrukcji mentalnych procesów translacyjnych o wyniki badań okulograficznych i ankietowych
}

\begin{abstract}
Expanding basics for modeling of mental processes using Eye-Tracking and post-hoc questionnaires

The Eye-Tracking Experimental Linguistics Laboratory conducted a study on translation process of German administrative acts into Polish. The aim of the study was to identify eye movements and associated mental processes during the perception of parts of speech in the German administrative acts (source text) during the translation process. Research method: The study was carried on a group of 15 participants. Eye-tracking analisys was performed using SMI RED 500 eyetracker and utilized the method of dynamic areas of interest (Dynamic AOI). Dyamic AOI-based method allowed the participants to freely move the windows on the monitor, use a PDF document, a text editor and a web browser at the same time. Results: Fixation duration $(\mathrm{Fd})$ and Fixation Count $(\mathrm{Fc})$ counts were significantly higher during perception of target text (Polish) than source text (German). There were no significant differences in FD between parts of the speech in source text, unlike the target text there were multiple differences were observed. In both source and final text there were multiple differences in Fc between different parts of the speech. There were no significant differences between perception of nouns and non-nouns in either text.Conclusions: Fixation count and fixation duration seem to be related with different mental processes during translation. Therefore, measuring eye movement with those parameters might be useful in further studies on translation process. Fixation count was more useful in investigating of mental processes than fixation duration.
\end{abstract}

\section{Wstęp ${ }^{1}$}

Poznawanie procesów mentalnych zachodzących w głowie tłumacza jest znacznie utrudnione z powodu niemożliwości ich bezpośredniej obserwacji. Użycie okulografu w celu zbadania procesów mentalnych umożliwia zmierzenie wskaźników okoruchowych i ich powiązanie z procesami mentalnymi zachodzącymi w głowie thumacza. To właśnie tłumacz z jego kompetencjami (właściwościami) translacyjnymi jest głównym obiektem zainteresowania translatoryki antropocentrycznej (por. S. Grucza 2014). W niniejszym artykule przedstawione będą wyniki analizy statystycznej wy-

\footnotetext{
${ }^{1} \mathrm{~W}$ tym miejscu pragnę serdecznie podziękować Panu Profesorowi Samborowi Gruczy za wszelką pomoc okazaną podczas sporządzania niniejszego artykułu.
} 
branych parametrów okulograficznych oraz na tej podstawie wyciągnięte będą wnioski dotyczące procesów mentalnych zachodzących w głowie thumacza w procesie tłumaczenia niemieckich aktów administracyjnych na język polski.

\section{Założenie okulograficzne}

Podstawą teoretyczną moich rozważań stanowi translatoryka antropocentryczna F. Gruczy (1981) i S. Gruczy (2014) oraz translatoryka okulograficzna S. Gruczy (2011). Zainteresowanie badaniami okulograficznymi w translatoryce bazuje na następującym przekonaniu:

U podstaw tego zainteresowania leży przekonanie, że ruchy gałek ocznych motywowane są zachodzącymi w mózgu osoby badanej procesami mentalnymi (kognitywnymi), i że w konsekwencji na podstawie ruchu gałek ocznych badanego można dokonać rekonstrukcji tych procesów, czyli sformułować hipotezy dotyczące procesów mentalnych (kognitywnych), jakie zachodzą w jego mózgu (S. Grucza 2011: 157).

N. Pavlović/ K.T.H. Jensen wiążą uwagę wzrokową skierowaną na tekst wyjściowy z procesami czytania i rozumienia tekstu wyjściowego, natomiast uwagę wzrokową skierowaną na tekst docelowy z procesami produkcji i kontroli tekstu docelowego:

We are assuming that the observable, measurable data that can be gained from eye tracking are indicators of unobservable cognitive processes happening in the subjects' mind during the translation tasks. In this assumption we rely on previous research on eye movements (...). We are furthermore assuming that the data related to the subjects' focus on the source text (ST) section of the screen are indicators of ST processing (reading, comprehension), while those data related to the subjects' focus on the target text (TT) section of the screen are related to TT processing (production, revision) (N. Pavlović/ K.T.H. Jensen 2009: 94).

Podstawowe założenie o powiązaniu procesów mentalnych z ruchami oczu rozwinęli M.A. Just i P.A. Carpenter²:

(...) the eye-mind assumption, is that the eye remains fixated on a word as long as the word is being processed. So the time it takes to process a newly fixated word is directly indicated by the gaze duration (M.A. Just/ P.A. Carpenter 1980: 330-331).

M. Płużyczka natomiast podnosi, że

(...) [b]adanie procesów, które zachodzą $\mathrm{w}$ głowie thumacza, poprzez analizę indykatorów tych procesów to, moim zdaniem, obecnie kluczowe zadanie poznawcze stojące przed współczesną translatoryką (M. Płużyczka 2015: 388).

${ }^{2}$ Stwierdzenie M.A. Justa/ P.A. Carpentera (1980) zostało częściowo podważone przez wyniki badań nad tłumaczeniem a vista M. Płużyczki (2015). 


\section{Metodologia badania ${ }^{3}$}

W Laboratorium Eksperymentalnej Lingwistyki Okulograficznej ${ }^{4}$ w Instytucie Komunikacji Specjalistycznej i Interkulturowej (IKSI) Uniwersytetu Warszawskiego przeprowadzono badanie okulograficzne procesu thumaczenia trzech niemieckich aktów administracyjnych na język polski. Piętnaście osób badanych podzielono na trzy pięcioosobowe grupy. Każda grupa tłumaczyła inny akt administracyjny. Następnie wszystkie uzyskane wyniki zostały przeanalizowane statystycznie.

(1) Tekst wyjściowy

Akt administracyjny ${ }^{5}$ określa prawa i obowiązki wskazanego adresata w indywidualnie oznaczonej sprawie (por. Wiktorowska 2001: 258), tworząc dla niego indywidualną i konkretną regułę zachowania. Termin ,akt administracyjny” jest prawie nie stosowany w przepisach prawa (tamże), natomiast używa się takich nazw, jak „decyzja administracyjna”, „postanowienie”, ,zezwolenie”, „,nakaz” (tamże). W polskim kodeksie postępowania administracyjnego umieszczone zostały przepisy dotyczące decyzji administracyjnej i postanowienia (patrz Ustawa z dnia 14 czerwca 1960 r. Kodeks postępowania administracynego). Na gruncie prawa polskiego w razie uprawomocnienia się decyzji administracyjnej staje się ona dla adresata decyzji obowiązującym prawem, które może być uchylone lub zmienione w trybie określonym w kodeksie postępowania administracyjnego oraz w ustawie Prawo o postępowaniu przed sądami administracyjnymi. Sentencja decyzji formułowana jest na podstawie norm prawa materialnego. Pozostałe elementy decyzji, to: oznaczenie organu, oznaczenie strony, uzasadnienie prawne i faktyczne, data wydania, pouczenie podpis organu bądź osoby reprezentującej organ, wynikają z przepisów procesowych i stanu faktycznego oraz zostały dookreślone przez orzecznictwo i doktrynę. Decyzje administracyjne zaliczyć należy do tekstów prawniczych, nie zaś prawnych (por. Internetowa Encyklopedia PWN). Jednakże warto zaznaczyć, że w decyzji administracyjnej sformułowana jest jednostronna reguła zachowania skierowana wobec adresata, która staje się dla niego obowiązującym prawem.

(2) Grupa badana

W badaniu uczestniczyło piętnaście studentów dziennych studiów magisterskich IKSI studiujących na kierunku: tłumaczenie specjalistyczne, język niemiecki wiodący i drugi angielski. Język polski był dla wszystkich badanych osób językiem ojczystym. Podczas semestru akademickiego studenci zapoznawali się z niemieckimi i polskimi aktami administracyjnymi.

\footnotetext{
${ }^{3}$ por. A. Bonek (2017: 124-127).

${ }^{4}$ www.lelo.iksi.uw.edu.pl

${ }^{5}$ Odnośnie różnic dotyczących polskich i niemieckich aktów administracyjnych patrz A. Bonek (2017).
} 


\section{(3) Warunki badania}

Podczas badania w laboratorium znajdowała się osoba badana oraz osoba nadzorująca badanie. Pomieszczenie było odizolowane od osób postronnych.

Warunki oświetlenia podczas badania wszystkich osób były podobne. Badania były przeprowadzane o podobnej porze dnia. Przed badaniem studenci byli poinformowani, że ich tłumaczenie nie będzie oceniane. W czasie tłumaczenia do dyspozycji studentów był słownik dwujęzyczny (A. Kilian/ A. Kilian 2009) oraz Internet. Czas tłumaczenia był nieograniczony.

\section{(4) Przebieg badania}

Osoby badane były poproszone o zapoznanie się z tekstem oraz jego przetłumaczenie. Następnie na monitorze pojawiał się tekst wyjściowy w formie PDF, edytor tekstu Word Pad oraz przeglądarka internetowa. Studenci mogli w sposób dowolny przesuwać i przybliżać wspomniane okna. O zakończeniu thumaczenia studenci informowali osobę nadzorującą.

(5) Badanie ankietowe

Po zakończeniu tłumaczenia studenci byli poproszeni o uzupełnienie krótkiej ankiety z następującymi pytaniami: „Czy oryginalny tekst niemiecki był dla Państwa zrozumiały” oraz „Które fragmenty tekstu sprawiły Państwu największą trudność podczas tłumaczenia. Proszę uzasadnić odpowiedź”.

(6) Parametry techniczne

Przekątna monitora wynosiła 22". W badaniu użyto okulografu firmy SMI typu RED 500. Częstotliwość próbkowania wyniosła $60 \mathrm{~Hz}$. Odległość od oczu badanych od monitora wynosiła ok. 50-70 cm, maksymalne odchylenie pomiaru $<0,4^{\circ}$, latencja (end to end): $<10 \mathrm{~ms}$, obszar śledzenia $40^{\circ} \mathrm{W}$ poziomie $\left( \pm 20^{\circ}\right), 60^{\circ} \mathrm{w}$ pionie $(+20 /-$ $\left.40^{\circ}\right)$.

(7) Metoda analizy danych

Dane uzyskane były z zastosowaniem metody dynamicznych obszarów zainteresowania (por. K. Holmqvist i in. 2011: 209). Tekst wyjściowy, tekst docelowy, przeglądarka internetowa, każdy pojedynczy wyraz w tekście wyjściowym oraz każdy wpisywany wyraz w tekście docelowym były zaznaczone jako obszary zainteresowania ${ }^{6}$.

W pierwszej części badania wybrano parametry, które używane były najczęściej $\mathrm{w}$ literaturze $\mathrm{w}$ badaniach nad procesem tłumaczenia oraz były, w mojej opinii, najbardziej miarodajne:

a) czas fiksacji i sakad (M. Płużyczka 2015);

b) czas fiksacji, liczbę fiksacji (F. Alves et al. 2016, M. Płużyczka 2015, S. Hansen-Schirra/ Ch. Rösener 2013, F. Alves/A. Pagano/ I. da Silva 2009, S. Sharmin et al. 2008);

${ }^{6}$ por. A. Bonek (2017: 127-130). 
c) szerokość źrenicy ${ }^{7}$ (M. Płużyczka 2015, Ch. M. Lachaud 2011, V.C-Y. Chang 2011, S. Göpferich 2008, O’Brien 2006).

Następnie badania zawężono do dwóch parametrów: liczby i czasu fiksacji. Zawężenie uzasadnione było chęcią zbadania sposobu funkcjonowania parametrów: czasu i liczby fiksacji oraz rozróżnienia procesów mentalnych z nimi powiązanych. $\mathrm{W}$ badaniu przeprowadzono analizę statystyczną z wykorzystaniem programu SPSS v 23. Normalność rozkładu sprawdzono testem W Shapiro-Wilka (A. Stanisz 2001). Dla danych nieparametrycznych zastosowano test Kruskala-Wallisa (por. A. Duchowsky 2006: 168). W analizie post hoc zastosowano test Manna-Whitneya.

\section{Wyniki badania okulograficznego}

\subsection{Porównanie trzech obszarów zainteresowania: tekst wyjściowy, tekst doce- lowy i przeglądarka internetowa ${ }^{8}$}

W tabeli 1 przedstawiono różnice w recepcji poszczególnych obszarów zainteresowania tekstu wyjściowego [TW], tekstu docelowego [TD] i przeglądarki internetowej [PI@] dla czterech parametrów. Kolorem szarym zaznaczono wyniki nieistotne statystycznie.

\begin{tabular}{c|c|c|c|c} 
& $\begin{array}{c}\text { Czas fiksacji i } \\
\text { sakad }\end{array}$ & Czas fiksacji & Liczba fiksacji & $\begin{array}{c}\text { Średnia } \\
\text { średnica źrenicy }\end{array}$ \\
\hline TW TD & $\mathrm{p}=0.002[$ TD] & $\mathrm{p}=0.015$ [TD] & $\mathrm{p}=0.006$ TD & $\mathrm{p}=0.663$ \\
\hline TD PI@ & $\mathrm{p}=0.015[\mathrm{TD}]$ & $\mathrm{p}=0.033$ [TD] & $\mathrm{p}=0.054$ & $\mathrm{p}=0.590$ \\
\hline TW PI@ & $\mathrm{p}=0.787$ & $\mathrm{p}=0.950$ & $\mathrm{p}=0.967$ & $\mathrm{p}=1.000$
\end{tabular}

Tabela 1. Różnice w recepcji trzech obszarów zainteresowania: tekst wyjściowy [TW], tekst docelowy [TD] oraz przegladarka internetowa [PI@].

Na podstawie wyników tabeli 1 można stwierdzić, że dwa parametry: czas fiksacji i sakad oraz czas fiksacji wykazały największą liczbę istotnych statystycznie wyników (oznaczenia kolorem czarnym). Oba parametry były istotnie statystycznie większe podczas recepcji tekstu docelowego porównując tekst docelowy z tekstem wyjściowym $(\mathrm{p}<0,05)$ oraz podczas recepcji tekstu docelowego porównując tekst docelowy $\mathrm{z}$ przeglądarką internetową $(\mathrm{p}<0.05)$. Żaden $\mathrm{z}$ badanych parametrów nie wykazał istotnych statystycznie różnic pomiędzy recepcją tekstu wyjściowego i przeglądarki internetowej $(\mathrm{p}>0,05)$ (oznaczenia kolorem szarym). Parametr średniej średnicy źrenicy nie wykazał żadnych istotnych statystycznie różnic podczas recepcji trzech badanych obszarów zainteresowania $(p>0,05)$. Zatem wydawać się może, iż jego użycie parametru dla mniejszych obszarów zainteresowania, takich jak poszczególne wyrazy, może nie wykazać istotnych statystycznie różnic (podobnie M. Płużyczka 2015).

\footnotetext{
${ }^{7}$ W badaniu M. Płużyczki (2015) udowodniono, że parametr rozszerzenia źrenicy nie jest miarodajny na małych jednostkach analizy, takich jak wyrazy. W badaniu A. Bonek (2017) wspomniany parametr był użyty dla zbadania różnic w recepcji formatowań wyrazów. ${ }^{8}$ por. A. Bonek (2017: 164-174).
} 
Jednakże parametr ten użyto przy badaniu różnic w recepcji sformatowanych wyrazów w badanych aktach administracyjnych i otrzymano istotne statystycznie wyniki (por. A. Bonek 2017).

\section{Proces tlumaczenia ${ }^{9}$}

\subsection{Recepcja tekstu wyjściowego}

\section{(1) Czas fiksacji}

Celem niniejszej części pracy jest zbadanie różnic w recepcji poszczególnych części mowy podczas procesu tłumaczenia. Najpierw użyto testku Kruskala-Wallisa, zaś w analizie post hoc zastosowano test Manna-Whitneya (patrz pkt. 2.7). Test KruskalaWallisa umożliwia porównanie maksymalnie 10 grup (A. Stanisz 2001: 276). Dlatego wybrano następujące części mowy: grupa rzeczowników, czasowników, przymiotników, spójników, przysłówków, zaimków, rodzajników i przyimków oraz dla porównania grupę sformatowanych rzeczowników-terminów oraz niesformatowanych rzeczowników-terminów.

\begin{tabular}{lll}
$\begin{array}{l}\text { Obszar pomiaru } \\
\text { Średnia ranga }\end{array}$ & $\begin{array}{l}\text { Obszar pomiaru } \\
\text { Średnia ranga }\end{array}$ & Istotność statystyczna \\
\hline Rzeczowniki & $\begin{array}{l}\text { Sformatowane rzeczowniki- } \\
\text { terminy }\end{array}$ & $\mathrm{p}=0,000$ \\
{$[503,12]$} & {$[438,52]$} & \\
\hline Rzeczowniki-terminy & Sformatowane rzeczowniki- & $\mathrm{p}=0,003$ \\
{$[571,43]$} & terminy & \\
& {$[515,69]$} & $\mathrm{p}=0,020$ \\
\hline Rzeczowniki & Przyimki & \\
{$[234,02]$} & {$[200,54]$} &
\end{tabular}

Tabela 2. Istotne statystycznie wyniki dla parametru czas fiksacji.

Po przeprowadzeniu analizy statystycznej tylko trzy kombinacje grup zmiennych:

a) sformatowane rzeczowniki-terminy i rzeczowniki,

b) sformatowane rzeczowniki-terminy i rzeczowniki-terminy i

c) rzeczowniki i przyimki

wykazały istotnie statystyczną różnicę podczas ich recepcji w tekście wyjściowym dla parametru czas fiksacji. Pozostałe kombinacje zmiennych nie wykazały istotnych statystycznie różnic. Wyliczenia zaprezentowane w tabeli nr 2 wykazały, iż 1) rzeczowniki miały istotnie dłuższe fiksacje niż sformatowane rzeczowniki-terminy, 2) rzeczowniki-terminy miały istotnie statystycznie dłuższe fiksacje niż sformatowane rzeczowniki-terminy oraz 3) niesformatowane rzeczowniki miały istotnie statystycznie dłuższe fiksacje niż przyimki. Ponadto należy zauważyć, że formatowania użyte dla

${ }^{9}$ por. A. Bonek (2017: 187-198). 
podkreślenia poszczególnych części mowy nie wpłynęły na długość fiksacji._Pozostałe kombinacje części mowy wspomniane w pkt. 4.1.1 nie wykazały istotnych statystycznie różnic.

(2) Liczba fiksacji

W poniższej tabeli przedstawiono wszystkie otrzymane istotne statystycznie wyniki $(\mathrm{p}<0,05)$. Pozostałe kombinacje badanych grup nie wykazały istotnych różnic $(\mathrm{p}>$ $0,05)$.

\begin{tabular}{|c|c|c|}
\hline $\begin{array}{l}\text { Obszar pomiaru } \\
\text { [Średnia ranga] }\end{array}$ & $\begin{array}{l}\text { Obszar pomiaru } \\
\text { [Średnia ranga] }\end{array}$ & Istotność statystyczna \\
\hline $\begin{array}{l}\text { Sformatowane rzeczowniki- } \\
\text { terminy } \\
{[200,83]}\end{array}$ & $\begin{array}{l}\text { Rzeczowniki } \\
{[166,14]}\end{array}$ & $\mathrm{p}=0,001$ \\
\hline $\begin{array}{l}\text { Sformatowane rzeczowniki-terminy } \\
{[152,12]}\end{array}$ & $\begin{array}{l}\text { Rzeczowniki-terminy } \\
{[133,00]}\end{array}$ & $p=0,045$ \\
\hline $\begin{array}{l}\text { Sformatowane rzeczowniki-terminy } \\
{[126,77]}\end{array}$ & $\begin{array}{l}\text { Czasowniki } \\
{[91,36]}\end{array}$ & $\mathrm{p}=0,000$ \\
\hline $\begin{array}{l}\text { Sformatowane rzeczowniki- terminy } \\
{[109,88]}\end{array}$ & $\begin{array}{l}\text { Przymiotniki } \\
{[92,88]}\end{array}$ & $\mathrm{p}=0,050$ \\
\hline $\begin{array}{l}\text { Sformatowane rzeczowniki-terminy } \\
{[109,77]}\end{array}$ & $\begin{array}{l}\text { Przysłówki } \\
{[75,88]}\end{array}$ & $\mathrm{p}=0,000$ \\
\hline $\begin{array}{l}\text { Sformatowane rzeczowniki-terminy } \\
{[166,58]}\end{array}$ & $\begin{array}{l}\text { Przyimki } \\
{[109,53]}\end{array}$ & $\mathrm{p}=0,000$ \\
\hline $\begin{array}{l}\text { Sformatowane rzeczowniki-terminy } \\
{[96,73]}\end{array}$ & $\begin{array}{l}\text { Spójniki } \\
{[60,56]}\end{array}$ & $\mathrm{p}=0,000$ \\
\hline $\begin{array}{l}\text { Sformatowane rzeczowniki-terminy } \\
{[153,61]}\end{array}$ & $\begin{array}{l}\text { Rodzajniki } \\
{[100,92]}\end{array}$ & $\mathrm{p}=0,000$ \\
\hline $\begin{array}{l}\text { Sformatowane rzeczowniki-terminy } \\
{[116,89]}\end{array}$ & $\begin{array}{l}\text { Zaimki } \\
{[75,48]}\end{array}$ & $\mathrm{p}=0,000$ \\
\hline $\begin{array}{l}\text { Rzeczowniki-terminy } \\
{[115,53]}\end{array}$ & $\begin{array}{l}\text { Czasowniki } \\
{[95,03]}\end{array}$ & $\mathrm{p}=0,012$ \\
\hline $\begin{array}{l}\text { Rzeczowniki-terminy } \\
{[100,37]}\end{array}$ & $\begin{array}{l}\text { Przysłówki } \\
{[79,14]}\end{array}$ & $\mathrm{p}=0,012$ \\
\hline $\begin{array}{l}\text { Rzeczowniki-terminy } \\
{[141,21]}\end{array}$ & $\begin{array}{l}\text { Rodzajniki } \\
{[104,21]}\end{array}$ & $\mathrm{p}=0,000$ \\
\hline $\begin{array}{l}\text { Rzeczowniki-terminy } \\
{[107,16]}\end{array}$ & $\begin{array}{l}\text { Zaimki } \\
{[78,88]}\end{array}$ & $\mathrm{p}=0,001$ \\
\hline $\begin{array}{l}\text { Rzeczowniki-terminy } \\
{[88,55]}\end{array}$ & $\begin{array}{l}\text { Spójniki } \\
{[64,05]}\end{array}$ & $\mathrm{p}=0,008$ \\
\hline
\end{tabular}




\begin{tabular}{|c|c|c|}
\hline $\begin{array}{l}\text { Rzeczowniki-terminy } \\
{[153,21]}\end{array}$ & $\begin{array}{l}\text { Przyimki } \\
{[112,88]}\end{array}$ & $\mathrm{p}=0,000$ \\
\hline $\begin{array}{l}\text { Rzeczowniki } \\
{[184,10]}\end{array}$ & $\begin{array}{l}\text { Przyimki } \\
{[149,74]}\end{array}$ & $\mathrm{p}=0,001$ \\
\hline $\begin{array}{l}\text { Rzeczowniki } \\
{[173,19]}\end{array}$ & $\begin{array}{l}\text { Rodzajniki } \\
{[140,91]}\end{array}$ & $\mathrm{p}=0,001$ \\
\hline $\begin{array}{l}\text { Rzeczowniki } \\
{[141,65]}\end{array}$ & $\begin{array}{l}\text { Zaimki } \\
{[116,12]}\end{array}$ & $\mathrm{p}=0,017$ \\
\hline $\begin{array}{l}\text { Przymiotniki } \\
{[184,10]}\end{array}$ & $\begin{array}{l}\text { Przyimki } \\
{[149,74]}\end{array}$ & $\mathrm{p}=0,001$ \\
\hline $\begin{array}{l}\text { Przymiotniki } \\
{[113,54]}\end{array}$ & $\begin{array}{l}\text { Spójniki } \\
{[87,17]}\end{array}$ & $\mathrm{p}=0,001$ \\
\hline $\begin{array}{l}\text { Przymiotniki } \\
{[50,14]}\end{array}$ & $\begin{array}{l}\text { Rodzajniki } \\
{[37,98]}\end{array}$ & $\mathrm{p}=0,028$ \\
\hline $\begin{array}{l}\text { Przymiotniki } \\
{[68,38]}\end{array}$ & $\begin{array}{l}\text { Zaimki } \\
{[52,63]}\end{array}$ & $\mathrm{p}=0,008$ \\
\hline $\begin{array}{l}\text { Przymiotniki } \\
{[61,80]}\end{array}$ & $\begin{array}{l}\text { Przysłówki } \\
{[50,38]}\end{array}$ & $\mathrm{p}=0,049$ \\
\hline
\end{tabular}

Tabela 3. Istotne statystycznie wyniki dla parametru liczba fiksacji.

Otrzymano znaczną liczbę istotnych wyników podczas recepcji sformatowanych rzeczowników-terminów, niesformatowanych rzeczowników-terminów, niesformatowanych rzeczowników oraz przymiotników. W ankiecie osoby badane wskazały, że to właśnie rzeczowniki-terminy oraz niesformatowane rzeczowniki-terminy. Sprawiły im największe trudności translacyjne. Ponadto nie stwierdzono m.in. różnic w recepcji rzeczowników-terminów i zwykłych rzeczowników oraz rzeczowników i czasowników, a także rzeczowników i przymiotników. Zatem można wysnuć wniosek, że są one recypowane, a zatem i przetwarzane w sposób jednolity.

Sformatowane rzeczowniki-terminy miały istotnie większą liczbę fiksacji niż wszystkie pozostałe badane części mowy. Niesformatowane rzeczowniki-terminy natomiast uzyskały większą liczbę fiksację w porównaniu z spójnikami, przysłówkami, rodzajnikami i zaimkami, co wynikać może ze stosunkowo małego obszaru pomiaru, które zajmowały. Natomiast porównując recepcję rzeczowników-terminów do czasowników, to czasowniki uzyskały mniejszą liczbę fiksacji niż rzeczowniki-terminy.

Przymiotniki również uzyskały istotnie statystycznie większe wartości, co jednakże nie znalazło odzwierciedlenia w odpowiedziach studentów. Jednakże dla zrozumienia tekstu wyjściowego miały one duże znaczenie.

\subsection{Tekst docelowy}

(1) Czas fiksacji

Dla analizy wybrano następujące grupy: zamki, rzeczowniki, rzeczowniki-terminy, liczby, przysłówki, przymiotniki, przyimki, czasowniki, spójniki. Z obliczeń wynika, 
że parametr czasu fiksacji nie wykazał istotnych statystycznie różnic podczas recepcji poszczególnych grup w tekście docelowym $(\mathrm{p}>0,05)$. Podczas recepcji tekstu wyjściowego otrzymano zaledwie trzy istotne statystycznie wyniki (patrz. tab.2).

(2) Liczba fiksacji

W poniższej tabeli przedstawiono wszystkie otrzymane istotne statystycznie wyniki $(\mathrm{p}<0,05)$. Pozostałe kombinacje badanych grup nie wykazały istotnych różnic ( $\mathrm{p}>$ $0,05)$.

\begin{tabular}{|c|c|c|}
\hline $\begin{array}{l}\text { Grupa zmiennych } \\
\text { Średnia ranga }\end{array}$ & $\begin{array}{l}\text { Grupa zmiennych } \\
\text { Średnia ranga }\end{array}$ & Istotność statystyczna \\
\hline $\begin{array}{l}\text { Rzeczowniki-terminy } \\
{[166,79]}\end{array}$ & $\begin{array}{l}\text { Czasowniki } \\
{[147,83]}\end{array}$ & $\mathrm{p}=0,034$ \\
\hline $\begin{array}{l}\text { Rzeczowniki-terminy } \\
{[268,49]}\end{array}$ & $\begin{array}{l}\text { Przyimki } \\
{[209,30]}\end{array}$ & $\mathrm{p}=0,000$ \\
\hline $\begin{array}{l}\text { Liczby } \\
{[171,19]}\end{array}$ & $\begin{array}{l}\text { Rzeczowniki-terminy } \\
{[149,20]}\end{array}$ & $\mathrm{p}=0,021$ \\
\hline $\begin{array}{l}\text { Rzeczowniki-terminy } \\
{[108,31]}\end{array}$ & $\begin{array}{l}\text { Czasowniki } \\
{[91,00]}\end{array}$ & $p=0,050$ \\
\hline $\begin{array}{l}\text { Liczby } \\
{[455,50]}\end{array}$ & $\begin{array}{l}\text { Rzeczowniki } \\
{[401,13]}\end{array}$ & $\mathrm{p}=0,005$ \\
\hline $\begin{array}{l}\text { Rzeczowniki } \\
{[359,80]}\end{array}$ & $\begin{array}{l}\text { Przysłówki } \\
{[301,08]}\end{array}$ & $\mathrm{p}=0,050$ \\
\hline $\begin{array}{l}\text { Rzeczowniki } \\
{[519,53]}\end{array}$ & $\begin{array}{l}\text { Przyimki } \\
{[397,27]}\end{array}$ & $\mathrm{p}=0,000$ \\
\hline $\begin{array}{l}\text { Rzeczowniki } \\
{[418,44]}\end{array}$ & $\begin{array}{l}\text { Czasowniki } \\
{[368,37]}\end{array}$ & $\mathrm{p}=0,009$ \\
\hline $\begin{array}{l}\text { Rzeczowniki } \\
{[357,07]}\end{array}$ & $\begin{array}{l}\text { Spójniki } \\
{[294,99]}\end{array}$ & $\mathrm{p}=0,050$ \\
\hline $\begin{array}{l}\text { Liczby } \\
{[100,84]}\end{array}$ & $\begin{array}{l}\text { Przysłówki } \\
{[73,26]}\end{array}$ & $\mathrm{p}=0,002$ \\
\hline $\begin{array}{l}\text { Liczby } \\
{[97,76]}\end{array}$ & $\begin{array}{l}\text { Spójniki } \\
{[70,13]}\end{array}$ & $\mathrm{p}=0,003$ \\
\hline $\begin{array}{l}\text { Przymiotniki } \\
{[322,20]}\end{array}$ & $\begin{array}{l}\text { Przyimki } \\
{[253,13]}\end{array}$ & $\mathrm{p}=0,000$ \\
\hline $\begin{array}{l}\text { Przymiotniki } \\
{[221,35]}\end{array}$ & $\begin{array}{l}\text { Czasowniki } \\
{[199,85]}\end{array}$ & $\mathrm{p}=0,050$ \\
\hline
\end{tabular}

Tabela 4. Istotne statystycznie wyniki dla parametru liczba fiksacji. 
Tabela 4 przedstawia wszystkie otrzymane istotne statystycznie wyniki dla wszystkich kombinacji grup zmiennych badanych parami. Rzeczowniki-terminy oraz rzeczowniki w porównaniu $\mathrm{z}$ innymi zmiennymi miały najwięcej istotnie statystycznych wyników, co potwierdza badanie ankietowe. Nie stwierdzono różnic w recepcji rzeczowników-terminów oraz rzeczowników nie będących terminami. Ponadto liczby uzyskały większą liczbę fiksacji podczas recepcji i ich produkcji w tekście docelowym.

\section{Wyniki badania ankietowego}

Wszystkie osoby badane zaznaczyły, że tekst oryginalny w języku niemieckim był dla nich zrozumiały. Odpowiadając na drugie pytanie dotyczące trudności translacyjnych osoby badane podały 36 rzeczowników-terminów, które, ich zdaniem, sprawiły im najwięcej trudności podczas tłumaczenia. Żadne pozostałe części mowy nie były wymienione.

Porównując wyniki badania ankietowego z wynikami badania okulograficznego można stwierdzić, że w największej mierze wyniki badania ankietowego odzwierciedla parametr liczby fiksacji.

\section{Podsumowanie wyników badania okulograficznego}

W tabeli 5 przedstawiono podsumowanie otrzymanych wyników dla dwóch parametrów: czasu fiksacji i liczby fiksacji.

\begin{tabular}{lll}
\hline $\begin{array}{l}\text { Obszar } \\
\text { pomiaru }\end{array}$ & TW [DE] & TD \\
Obszar tekstu & czas fiksacji & $\begin{array}{l}\text { [PL] } \\
\text { czas fiksacji }\end{array}$ \\
Obszar tekstu & liczba fiksacji & $<$ liczba fiksacji \\
Obszar wyrazu & czas fiksacji & czas fiksacji \\
Liczba istotnych statystycznie wyników & 3 & 0 \\
Obszar wyrazu & liczba fiksacji & liczba fiksacji \\
Liczba istotnych statystycznie wyników & 23 & 13 \\
\hline
\end{tabular}

Tabela 5. Podsumowanie dotychczasowych wyników.

Z pierwszych dwóch wierszy tabeli 5 wynika, że parametr czasu fiksacji oraz liczby fiksacji był istotnie statystycznie wyższy podczas recepcji tekstu docelowego w języku ojczystym, niż tekstu wyjściowego w języku niemieckim.

Piąty wiersz tabeli 5 przedstawia liczbę otrzymanych istotnych statystycznie wyników dla parametru czasu fiksacji podczas recepcji tekstu wyjściowego (3) i docelowego (0). Podsumowując trzy istotne statystycznie wyniki otrzymane podczas recepcji tekstu wyjściowego można stwierdzić, że sformatowane rzeczowniki-terminy miały znacznie krótsze fiksacje, niż niesformatowane rzeczowniki i rzeczowniki-terminy. Przyimki natomiast były znacznie dłużej recypowane niż rzeczowniki. Użyte formatowania dla podkreślenia rzeczowników nie wydłużyły czasu ich recepcji. Badanie ankietowe potwierdza problemy z poszukiwaniem polskich odpowiedników dla 
niemieckich rzeczowników i rzeczowników-terminów Natomiast podczas recepcji tekstu docelowego dla parametru czasu fiksacji nie stwierdzono istotnych statystycznych różnic. Dla parametru liczby fiksacji otrzymano podczas recepcji tekstu wyjściowego 23, zaś tekstu docelowego 13 istotnych statystycznie wyników (siódmy wiersz tabeli 5).

\section{Wnioski}

Procesy mentalne związane $\mathrm{z}$ tworzeniem tekstu docelowego oraz rozwiązywaniem problemów translacyjnych w tekście docelowym były znacznie intensywniejsze niż podczas recepcji tekstu wyjściowego. Badanie ankietowe potwierdza otrzymany wynik, gdyż zgodnie z odpowiedziami osób badanych rozumienie tekstu wyjściowego nie sprawiło im trudności. Natomiast w badaniu ankietowym studenci zaznaczali, że odnajdywanie polskich odpowiedników przysporzyło im najwięcej pracy

Skoro parametr czasu fiksacji nie wykazał istotnych różnic $\mathrm{w}$ recepcji poszczególnych części mowy w języku ojczystym, a parametr liczby fiksacji wykazał bardzo dużą liczbę istotnych statystycznie wyników zarówno w tekście w j. ojczystym i obcym, to wnioskować można, że oba parametry wiązać się mogą z różnymi procesami mentalnymi.

Parametr czasu fiksacji nie wykazał istotnych różnic w recepcji poszczególnych części mowy w język ojczystym, natomiast uzyskał istotne wyniki podczas recepcji części mowy w języku obcym. Można wnioskować, że procesy mentalne związane z tym parametrem były jednolite (brak istotnych statystycznie różnic) oraz nie odbywały się na poziomie części mowy. Ponadto parametr ten okazał się być niemiarodajny dla badania problemów translacyjnych, z którymi zetknęli się młodzi thumacze.

Procesy mentalne związane z parametrem liczby fiksacji wyraźnie wiążą się z przetwarzaniem na poziomie części mowy. Zatem parametr ten okazał się być miarodajny dla stwierdzeniu problematów translacyjnych. Zdaniem M. Płużyczki (2015: 390) „wszystkie parametry mogą zostać w pewnym zakresie uznane za indykatory stopnia obciążenia kognitywnego, ale w różnym stopniu i nie na wszystkich jednostkach analizy."

Nie stwierdzono istotnej statystycznie różnicy pomiędzy recepcją rzeczowników i rzeczowników-terminów podczas recepcji tekstów w języku niemieckim oraz polskim. Zatem można przypuszczać, że nie było różnicy w recepcji rzeczowników niebędących terminami i rzeczowników będących terminami. Otrzymany wynik potwierdza stwierdzenie S. Gruczy, że „w rzeczywistości nie ma wyraźnej granicy między terminami a nieterminami, a w każdym razie między naturalnymi terminami a nieterminami” (2013: 87).

Parametr średniej średnicy źrenicy nie wykazał istotnych statystycznie wyników podczas recepcji obszarów zainteresowania zarówno na poziomie całego tekstu, jak i poziomie wyrazów. Parametr ten wykazał istotne statystycznie różnice w recepcji formatowań użytych w tekście (patrz A. Bonek 2017).

Procesy mentalne nakierowane na rozwiązywanie problemów translacyjnych powiązać można z parametrem liczby fiksacji, gdyż osoby badane podawały właśnie rzeczowniki-terminy i rzeczowniki jako wyrazy stwarzające im najwięcej trudności 
translacyjnych. Ponadto badanie okulograficzne uzupełnia badanie ankietowe wykazując, że oprócz rzeczowników-terminów i rzeczowników problemy translacyjne przysporzyły osobom badanym tłumaczenie przymiotników oraz produkcja liczb w tekście docelowym.

\section{Bibliografia}

Alves, F./ A. Koglin/ B. Mesa-Lao/ M.G. Martinez/ N.B. de Lima Fonseca/ A. De Melo Sa/ J. L. Gonçalves/ K. Sarto Szpak/ K. Sekino/ M. Aquino (2016), Analysing the Impact of Interactive Machine Translation, (w:) M. Carl/ S. Banhalore/ M. Schaeffer (red.), New Directions in Empirical Translation Process Research. Exploring the CRITT TPR-DB. Frederiksberg, 77-95

Alves, F./ A. Pagano/ I.A.L. da Silva (2009), A new window of translators cognitive activity: methodological issues in the combined use of eye tracking, key logging and retrospective protocols, (w:) I.M. Mees/ F. Alves/ S. Göpferich (red.), Methodology, Technology and Innovation in Translation Process Research (Copenhagen Studies in Language 38). Frederiksberg, 277-291.

Bonek, A. (2017), Eyetracking-Analyse computergestützten Übersetzungsprozesses. Warszawa.

Duchowski, A. (2003), Eye Tracking Methodology: Theory and Practice. New York.

Chang, V.C.Y. (2011), Translation Directionality and the Revised Hierarchical Model: An Eye-Tracking Study, (w:) Sh. O’Brien (red.), Cognitive Explorations of Translation. London/New York, 154-175.

Göpferich, S. (2008), Translationsprozessforschung: Stand-Methoden-Perspektiven. Tübingen.

Grucza, F. (1981) Zagadnienia translatoryki, (w:) F. Grucza (red.), Glottodydaktyka a translatoryka. Warszawa, 9-30.

Grucza, S. (2011), Lingwistyka antropocentryczna a badania okulograficzne, (w:) „Lingwistyka Stosowana - Applied Linguistics - Angewandte Linguistik” 4/ 2011, 149-162.

Grucza, S. (2014), Grundzüge der Anthropozentrischen Translatorik, (w:) A. ŁypBielecka (red.), Mehr als Worte. Sprachwissenschaftliche Studien. Katowice, 127-139.

Holmqvist, K./ M. Nyström/ R. Andersson/ R. Dewhurst/ H. Jarodzka/ J. van de Weijer (2011), Eye Tracking - A Comprehensive Guide to Methods and Measures. Oxford.

Hansen-Schirra, S./ Ch. Rösener (2013), Proactive Use of Eye-Tracking in the Translational Workflow, (w:) S. Grucza/ M. Płużyczka/ J. Zając (red.), Translation Studies and Eye-Tracking Analysis. Frankfurt a.M., 139-153.

Internetowa Encyklopedia PWN (URL https://encyklopedia.pwn.pl/haslo/jezykprawny-i-prawniczy;3917947.html). [Pobrano 02.10.2017].

Just, M.A./ P.A. Carpenter (1980), A Theory of Reading: From Eye Fixations to Comprehension, (w:) „Psychological Review”, Vol. 87, Nr. 4, 329-354. 
Kilian, A/ A. Kilian (2009), Słownik języka prawniczego i ekonomicznego. Warszawa.

Lauchaud, Ch.M. (2011), EEG, EYE and EY: Three Simultaneous treams of Data for Investigating the Cognitive Mechanisms of Translation, (w:) Sh. O'Brien (red.), Cognitive Esplorations of Translation. London, 131-154.

O'Brien, Sh. (2006), Eye-tracking and translation memory matches, (w:) „Perspectives: Studies in Translatology" 14, 185-205.

Pavlović, N./ K.T.H. Jensen (2009), Eye tracking translation directionality, (w:) A. Pym/ A. Perekrestenko (red.), Translation Research Projects 2. Traggona, Universitat Rovira i Virgili, 93-109.

Płużyczka, M. (2015), Tłumaczenie a vista. Rozważania teoretyczne i badania Eyetrackingowe. Warszawa

Stanisz, A. (2001), Przystępny kurs ze statystyki w oparciu o program STATISTICA PL na przykładach z medycyny. Kraków.

Sharmin, S./ O. Špakov/ K.J. Räihä/ A.L. Jakobsen (2008), Effects of Time Pressure and Text Complexity on Translators' Fixations, (w:) Eye Tracking Research \& Application Archive: Proceedings of the 2008 Symposium on Eye Tracking \& Applications, Savannah. Georgia, 26-29 march, 2008. Association for Computing Machinery, 123-126.

Ustawa z dnia 14 czerwca 1960 r. Kodeks postępowania administracyjnego (Dz.U. 1960 nr 30 poz. 168).

Wiktorowska, A. (2001), Prawne formy działania administracji, (w:) M. Wierzbowski/ Z. Cieślak/ J. Jagielski/ J. Lang/ M. Szubiakowski/ A. Wiktorowska (red.), Prawo Administracyjne. Warszawa, 253-286 